\begin{tabular}{cc|c}
\hline Tar. Bil. Der. & Tournal of Agricultural Sciences \\
& $\begin{array}{c}\text { Dergi web sayfası: } \\
\text { www.agri.ankara.edu.tr/dergi }\end{array}$ & Journal homepage: \\
& ww.agri.ankara.edu.tr/journal
\end{tabular}

\title{
Türkiye'de Kestane Kanseri ile Biyolojik Mücadelede Ümitvar Bulgular
}

\author{
N. Mükerrem ÇELIKER ${ }^{a}$, Ersin ONOĞUR ${ }^{b}$ \\ ${ }^{a}$ Bornova Zirai Mücadele Araștırma Enstitüsü, Gençlik Cad. No 6, 35040, İzmir, TÜRKIYE \\ ${ }^{b}$ Ege Üniversitesi, Ziraat Fakültesi, Bitki Koruma Bölümü, 35100, Bornova, İzmir, TÜRKIYYE
}

\section{ESER BÍLGISİ}

Araştırma Makalesi — Bitkisel Üretim ～DOI: 10.1501/Tarimbil_0000001164

Sorumlu Yazar: N. Mükerrem ÇELİKER, e-posta: nmukerrem@hotmail.com, Tel: +90(232) 38800

30/113 Geliş tarihi: 17 Haziran 2010, Düzeltmelerin gelişi: 15 Ağustos 2011, Kabul: 19 Ağustos 2011

\section{ÖZET}

Bu makalede, Manisa ili Hacıisalar köyündeki bir kestanelikte kestane kanseri hastalığının hipovirulent streynlerle biyolojik mücadelesiyle ilgili 2002-2005 yılları verileri ile 2007-2008 yıllarında hipovirulensin doğal yayılma durumunu saptamaya yönelik araştırma sonuçları verilmiştir. İlk etaptaki çalıșmada, deneme alanındaki hasta ağaçlardan sadece EU-1 uyum grubuna ve MAT1-1 eşleşme tipine ait virulent izolatlar elde edilmiştir. Ege Bölgesi kestaneliklerinde hipovirulent streyn saptanmadığı için, laboratuar koşullarında lokal bir virulent izolat Marmara bölgesinden elde edilen hipovirulent izolat yardımıyla yeni bir lokal hipovirulent streyne dönüștürülmüș ve bu streyn $\mathrm{HiSF}_{1}$ olarak kodlanmıştır. HiSF ${ }_{1}$ 'in EU-1 uyum grubu ve MAT1-1 eşleşme tipine ait olduğu belirlenmiş ve konversiyon testlerinde virulent izolatların tamamını hipovirulent karaktere dönüştürmüştür. Sonraki bölümde, kestanelikteki genç ağaçların üzerinde mevcut kanserlerin boyutları ölçüldükten sonra, bu kanserlerin çevresine $\mathrm{HiSF}_{1}$ 'in geliştiği koloni diskleri inokule edilmiş ve aylık dönemlerle kanserli dokudaki boyut değişimleri ölçülmüştür. Sonuçta, HiSF ${ }_{1}$ ile inokule edilen kanserlerin çoğunda kallus oluşumuna bağlı küçülme saptanırken, bazılarında aktif kanserlerin yüzeysel iyileşmiş kanser tipine dönüştüğü kaydedilmiştir. Her iki iyileşme belirtisinden hipovirulent streyn tekrar izole edilmiştir. Bu çalışmanın sona ermesinden sonra, deneme sahasındaki kestanelik sürekli olarak gözlem altında tutulmuştur. 2003 yılında yapılan inokulasyondan 4 yıl sonra, 2007-2008 yıllarında, hem önceden inokule edilmiş ve hem de inokule edilmemiş ağaçlarda hipovirulensin doğal yayılımı sonucunda yeni, iyileşmiş kanserlerin varlığı saptanmıştır.

Anahtar sözcükler: Kestane kanseri; Cryphonectria parasitica; Hipovirulent ırk; Doğal yayılım

\section{Promising Results on Biological Control of Chestnut Blight in Turkey}

\section{ARTICLE INFO}

Research Article - Crop Production

Corresponding author: N. Mükerrem ÇELİKER, e-mail: nmukerrem@hotmail.com, Tel: +90(232) 388 00 30/113

Received: 17 June 2010, Received in revised form: 15 August 2011, Accepted: 19 August 2011

\section{ABSTRACT}

In this study, results of studies about the biological control of chestnut canker with hypovirulent strains during 2002-2005 and natural dissemination of hypovirulence in the same chestnut stand during 2007-2008 in Manisa - 


\begin{abstract}
Haciisalar village in Turkey were reported. During the field and laboratory studies only virulent Cryphonectria parasitica isolates were obtained from the infected trees belonging to EU-1 vc-group and MAT1-1 mating type. During the conversion tests, hypovirulence could be tranmitted to all of these isolates by the local hypovirulent strain coded as $\mathrm{HiSF}_{1}$, which also belonged to ve type EU-1 and MAT1-1 mating type. Following this result, $\mathrm{HiSF}_{1}$ was inoculated onto cankered tissues of the infected trees, after measuring the length and width of the tissue and the changes in the dimensions of infected area were measured monthly. It was recorded that most of the active cankers treated with the HiSF were becoming smaller by forming callus tissue and some others were changing from active growing type to healed-superficial cankers. HiSF was re-isolated from both of those healing canker types. After completion of this study, the research area was visited at certain intervals in order to follow the canker development on the trees, and four years after inoculation, in 2007-2008, new healing cankers were recorded on inoculated as well as on non-inoculated trees, indicating that hypovirulence could spread naturally in the chestnut grove.
\end{abstract}

Keywords: Chestnut blight; Cryphonectria parasitica; Hypovirulent strain; Natural dissemination

(C) Ankara Üniversitesi Ziraat Fakültesi

\section{Giriş}

Kestane (Castanea sativa L.), kerestesi ve meyvesi nedeniyle önemli bir ağaçtır. Kestane kanseri (Cryphonectria parasitica Murr. Bar.) hastalığı, dünyanın ve Türkiye'nin kestane alanlarında yaygın ve çoğu kez ağaçların tamamen kurumasina neden olan önemli bir sorundur.

Kimyasal yolla mücadelesi mümkün olmayan hastalık, iç ve dış karantina önlemleri ve kültürel uygulamalarla kontrol edilmeye çalışılmakta (Anonymous 2008), ayrıca Avrupa ülkelerinde hipovirulent $C$. parasitica irkları yardımıyla başarılı bir şekilde biyolojik mücadelesi yapılmaktadır (Heiniger \& Rigling 1994). Türkiye'de de bu hedefe varmak üzere, çeşitli araştırıcılar tarafindan kestane yetiştiriciliği yapılan Ege, Marmara ve Karadeniz bölgelerinden izolat toplama, izolatlarm fenotipleri, uyum grupları ve eşleşme tiplerini belirleme, hipovirulenslik aktarımı gibi in vitro çalışmalar yanında (Açıkgöz et al 2007; Akıllı et al 2009; Çeliker \& Onoğur 2004, 2007; Coşkun et al 1999; Gürer et al 2001; Döken et al 2007), kontrollu koşullarda kestane fidanları kullanılarak in vivo çalışmalar da yürütülmüştür (Ak1llı et al. 2011; Aksoy et al. 2004).

Kestane kanseri hastalı̆̆ının biyolojik mücadelesiyle ilgili olarak, tarafimızdan yapılan çalışmalarda 1996-2000 yılları arasında Ege ve Marmara bölgelerinden 324 adet virulent izolat toplanmış ve Marmara bölgesinden dsRNA taşıdığı İsviçre Federal Orman Araştırma Enstitüsü tarafından testlenip onaylanmış 7 hipovirulent streyn elde edilmiştir (Çeliker \& Onoğur 1998). Kestane fidanlarına virulent ve hipovirulent 1 rkın birlikte yanyana inokule edilmesi halinde, bu birlikteliğin fidanlarda kanser oluşumunu yavaşlattığı ve zamanla kanserli dokunun iyileştiği gözlenmiştir (Çeliker \& Onoğur 2001). Bu çalışmalardan sonra, Türkiye'de doğal koşullarda, kestanelikte, hipovirulens aktarımı yoluyla biyolojik mücadele olanaklarını araştırmak üzere, 2002 - 2005 yılları arasında Manisa ili Haciisalar köyünde yer alan bir kestanelikte, hastalığın biyolojik mücadelesi yürütülmüştür (Çeliker \& Onoğur 2009a). 20072008 yılları arasında, aynı kestanelikte hipovirulensin kendiliğinden, doğal yayılma durumu ile ilgili gözlemler değerlendirilmiştir.

\section{Materyal ve Yöntem}

\subsection{Deneme alant, bitkisel ve fungal materyal}

Çalışma, Manisanın Hacıisalar köyünde, 3-7 yaşlı 93 ağacın bulunduğu, kestane kanseri hastalığının yanı sira Cytospora kanseri (Cytospora sp.) ile Armillaria (Armillaria mellea) kök çürüklügüü hastalıklarının da sorun olduğu bir kestanelikte yürütülmüştür. 2002 yılı ekim ayında, 93 kestane ağacından 25 adedinin hastalık belirtileri taşıdığ belirlenmiştir. $\mathrm{Bu}$ ağaçlar çalışmanın bitkisel materyalini oluşturmuştur.

Fungal materyaller;

a) Vejetatif uyum gruplarını ve eşleşme tiplerini belirlemek üzere, Dr.Ursula Heiniger ve Dr. Daniel Rigling'den (Swiss Federal Institute for Forest Snow and Landscape Research) temin 
edilen Avrupa Uyum Grubu izolatları, (EU-1 ve EU-12) ile Avrupa eşleşme tipi (MAT1-1/1297 ve MAT1-2/1115) izolatlar1,

b) Lokal hipovirulent streyn, "HiSF,",

c) Biyolojik mücadele çalışması yapılmadan önce, 2002 yılında çalışma alanındaki hasta 25 ağaçtan elde edilen ve in vitro testlerde kullanılan 25 adet virulent $C$. parasitica izolat,

d) Hipovirulent streynle 2003 yılinda inokule edilen 18 ağaç üzerindeki 29 kanserden elde edilen 102 adet re-izolat.

\subsection{Laboratuarda in vitro test çalışmaları}

Denemenin başlangıcında, 2002 yılı ekim ayında, 93 kestane ağacından 25 adedinin hastalık belirtileri taşıdığ 1 belirlenmiş çalışma alanındaki C. parasitica izolatlarının populasyon yapısını (izolatların fenotipi, vejetatif uyum grubu, eşleşme tipi) belirlemek üzere ağaçlardaki her bir kanserin 4 ayrı yönünden $4 \mathrm{~mm}$ çaplı mantar delici ile kabuk örnekleri alınmış, örnekler \%10'lik sodyum hipoklorit içinde 4 dak. tutulduktan sonra PDA (Patates Dekstroz Agar) besi yerine alınmıştır.

Re-izolasyon işleminde ise, ağaçların hipovirulent streyn ile inokulasyonundan 1 y1l sonra başlamak üzere, iyileşme belirtisi gösteren her bir kanserin yine 4 yönünden, mevsim içinde 1-3 kez kabuk örnekleri toplanmış ve yüzey sterilizasyondan sonra örnekler PDA besi yerine alınmış, elde edilen izolatlar tüplere saflaştırılmıştır.

Fenotip gruplandırma, çalışma alanından elde edilen $C$. parasitica izolatlarının turuncu (virulent) ya da beyaz ( hipovirulent ) olma durumlarını belirlemek için yapılmıştır. Her bir izolatın sporları steril iğne ile alınmış ve PDA ortamının 6 noktasına inokule edilmiştir. Deneme 2 tekerrürlü olarak yürütülmüştür. Petri kapları önce 7 gün süreyle $25^{\circ} \mathrm{C}$ sıcaklıktaki inkubatörde karanlıkta, daha sonra 7 gün süreyle oda sıcaklığında, gün ıșığında tutulmuştur (Bissegger et al 1997). Bu testler inokule edilen kanserlerden elde edilen re-izolatlar için de yapılmıştır.

Vejetatif uyum testi için çalışma alanından elde edilen her bir turuncu izolat ile Avrupa Uyum Grubu (EU-1, EU-12) izolatlarının her birine ait sporlar $0.3-0.4 \mathrm{~cm}$ aralıklarla ikișer ikişer PDA ortamına inokule edilmiştir. Yedi ve 12 gün sonra yapılan değerlendirmelerde, iki izolat tek bir koloni olarak gelişiyorsa "uyum var", aralarında baraj meydana geliyorsa "uyum yok" olarak kabul edilmiştir (Bissegger et al 1997). Deneme 2 tekerrürlü olarak yürütülmüsstür.

Ege bölgesinde hipovirulent irk saptanmadığ için, lokal virulent izolatlar önceki çalışmada (Çeliker \& Onoğur 1998), Marmara Bölgesinden (İzmit- Gölcük ve Karamürsel) izole edilmiş olan hipovirulent streynlerden bir tanesi ile aşağıda açıklandığı şekilde dönüştürülmüş ve böylelikle elde edilen lokal yeni hipovirulent streyn, "HiSF ${ }_{1}$ ", hem in vitro testlerde hem de biyolojik mücadele çalışmasında kullanılmıştır.

Konversiyon testleri, hipovirulent izolatların virulent izolatları dönüştürebilme yeteneklerini belirlemek için yapılmaktadır (Bissegger et al 1997). Bu yöntem uyarınca, 2 farklı gruba ait sporlar, vejetatif uyum grubu testinde olduğu gibi, PDA ortamı üzerinde ikişer ikişer eşleştirilmişler ve yine yukarıda belirtilen koşullarda geliştirilmişlerdir. İki izolat beyaz renkli tek bir koloni halinde gelişiyorsa bunlar arasında 'uyum var' olarak, aralarında baraj oluşuyor ve dönüşüm olmuyorsa 'uyum yok' olarak değerlendirmiştir (Bissegger et al 1997).

Dönüştürme yeteneği, kestane ağaçlarında hipovirulent streyn ile inokule edilmiş kanserlerden elde edilen beyaz renkli tüm reizolatlar için de belirlenmiştir.

Eşleşme tipini belirleme testleri, deneme alanında yeni uyum gruplarının meydana gelme olasılığını ortaya koyabilmek için yürütülmüştür. $\mathrm{Bu}$ amaçla, dormant dönemde toplanan $1.5-2 \mathrm{~cm}$ çaplı kestane sürgünleri önce boyuna, sonra enine $4 \mathrm{~cm}$ uzunluğunda kesilmiş ve otoklavda iki kez arka arkaya 1.5 atmosfer basınç altında 30 dak. süreyle sterilize edilmiştir. Her bir sürgün parçası $60 \mathrm{~mm}$ çaplı steril petri kabına yerleştirildikten sonra çevresine \%1,5'lik su agar ortamı dökülmüştür (Bissegger et al 1997). Testlerde, deneme alanından toplanan virulent izolatlar, lokal hipovirulent streyn $\mathrm{HiSF}_{1}$ ve Avrupa eşleşme tipi (MAT1-1, MAT1-2) izolatları 
kullanılmıştır. Çalıșmada, her bir izolatın PDA ortamında geliştirilmiş 7 günlük kültüründen alınan $4 \mathrm{~mm}$ büyüklüğündeki agar diskleri kullanılmıştır. Denemeler 2 tekrarlı yürütülmüştür.

Eşleşme tipi testleri turuncu ve beyaz izolatlar için farklı biçimde yürütülmüştür. Turuncu izolatlar için eşleşme testinde, petri kapları içindeki sürgün parçasının bir köşesine eşleşme tipi bilinen izolatlardan bir tanesi, çapraz köşesine ise eşleşme tipi bilinmeyen izolatlardan bir tanesi konmuş ve petri kutuları 14 gün süreyle $25^{\circ} \mathrm{C}$ 'de 16 saat aydınlatılarak (2.500 lux) spor oluşumu sağlanmıştır. $\mathrm{Bu}$ sürenin sonunda petrilere steril saf su konarak spor süspansiyonu elde edilmiştir (Bissegger et al 1997). Bu eşleşme testinde, sürgün parçasının bir köşesine eşleşme tipi bilinen izolatlardan bir tanesi tek başına inokule edilip spor oluşumu sağlanmıştır. Bu sırada, farklı petri kaplarında PDA ortamina inokule edilen hipovirulent izolatlar $25^{\circ} \mathrm{C}$ de, 10.000 lux işıkta (yüksek 1şık şiddetinde spor oluşturabilmeleri nedeniyle) 14 gün süreyle tutulmuş ve bu sürenin sonunda hazırlanan spor süspansiyonu eşleşme tipi belli olan izolatın geliştiği petri kabına eklenmiştir (Bissegger et al 1997).

Yukarıdaki uygulamalardan sonra petri kapları $18^{\circ} \mathrm{C}^{\prime}$ de 8 saat işıkta (2.500 lux), 16 saat karanlıkta tutulmuştur. Testin 2. ve 4. ayının sonunda dal parçalarının üzerinde eşeyli üreme kriteri olan peritesyum oluşumu yönünden değerlendirilme yapılmıştır. Çalışmada pozitif kontrol olarak iki eşleşme tipine ait izolatlar birlikte; negatif kontrol olarak ise her bir eşleşme tipine ait izolat ayrı ayrı inokule edilmiştir (Bissegger et al 1997).

\subsection{Kestanelikte yürütülen çalışmalar}

Çalışma alanında mevcut kestane ağaçlarının tümü numaralanmış ve yerleri alanın krokisi üzerine işaretlenmiştir.

Hipovirulent streynin inokulasyon çalışması 11.6.2003 tarihinde yürütülmüştür. İnokulasyondan 1 gün önce hasta olan tüm ağaçlar üzerindeki kanserlerin sayısı ve kanser boyutları bir şerit metre yardımıyla ölçülerek kaydedilmiştir. Toplam 18 hasta ağaç üzerindeki
29 aktif kanserin her birinin çevresinde, hastalıklı ve sağlıklı kabuk dokusunu kapsayacak şekilde, 2$3 \mathrm{~cm}$ aralıklarla $4 \mathrm{~mm}$ çaplı mantar delici ile delikler açılmıştır. Bu deliklere PDA ortamında, $26^{\circ} \mathrm{C}$ 'de karanlıkta 7 gün süreyle geliştirilen $\mathrm{HiSF}_{1}$ 'in kolonilerinden alınan agar diskleri yerleştirilmiş̧tir. Disklerin kurumaması için deliklerin üstü kağıt bantla kapatılmıştır.

Aynı yılın eylül ve ekim aylarında, deneme alanında yeni oluşan aktif kanserlere de inokulasyon yapılmıştır.

Kanser büyüklüğündeki değişimi saptamak için $\mathrm{HiSF}_{1}$ ile inokule edilen her bir kanserin eni ve boyu 1.5-2 aylık dönemlerle ölçülmüştür.

İnokulasyondan 1 y1l sonra, inokule edilmeyen ağaçlarda iyileşen karakterde kanser belirtilerinin varlığı kontrol edilmiştir.

\section{Bulgular ve Tartışma}

\subsection{In vitro test bulgulart}

Deneme alanında hastalı belirtisi taşıyan 25 kestane ağacından elde edilen 25 izolatın fenotipik özellikleri, vejetatif uyum grupları, $\mathrm{HiSF}_{1}$ kodlu hipovirulent streynin bu izolatları dönüştürme yeteneği hakkında elde edilen bulgular Cizelge 1'de, virulent izolatların ve hipovirulent streynin ait oldukları eşleşme tipleri ise Çizelge 2'de verilmiştir. Sonuç olarak, deneme alanında sadece virulent (turuncu renkli) $C$. parasitica izolatlarının var olduğu, bu izolatların hepsinin Avrupa Uyum Grubu izolatlarından sadece EU-1 ile vejetatif uyumlu olduğu saptanmıştır. Dönüştürme testinde ise, EU-1 uyum grubuna ait olan $\mathrm{HiSF}_{1} 25$ virulent izolatın hepsini beyaz forma dönüştürmüş, onlara hipovirulent karakter kazandırmıştır.

Çalışmada kullanılan tüm izolatların ve $\mathrm{HiSF}_{1}$ 'in MAT 1-1 eşleşme tipine ait oldukları belirlenmiştir. Turuncu izolatların tamamı ve $\mathrm{HiSF}_{1}$, MAT1-1 ile eşleştirildiklerinde peritesyum oluşmazken, MAT1-2 ile eşleştirildiklerinde peritesyum meydana gelmiştir. $\mathrm{Bu}$ sonuçlar, çalışma alanında yeni uyum gruplarının oluşma olasılığının bulunmadığını göstermektedir. Çünkü eşeyli üreme farklı eşey tipleri (MAT1-1 ve MAT1-2) arasında gerçekleşmektedir (Marra \& 
Çizelge 1-Deneme alanındaki C. parasitica izolatlarının fenotipik özellikleri, vejetatif uyum grupları ve lokal hipovirulent streyn HiSF1'in dönüş̧ürme yeteneği

Table 1-Cultural phenotypes and vegetative compability (v-c) groups of the C. parasitica isolates in the research area and conversion ability of the local hypovirulent strain, HiSF1

\begin{tabular}{|c|c|c|c|c|}
\hline \multirow[t]{2}{*}{ Izolat sayısı } & \multirow[t]{2}{*}{ Fenotip } & \multicolumn{2}{|c|}{ Vejetatif uyum grubu } & Dönüsstürme Yeteneğ $i$ \\
\hline & & EU-1 & EU-12 & HiSF $_{1}$ \\
\hline 25 & Turuncu & + & - & + \\
\hline
\end{tabular}

$(+)$ : Pozitif; (-): Negatif

Çizelge 2-Deneme alanındaki C. parasitica izolatlarının ve lokal hipovirulent streyn HiSF1'in eşleşme tipleri

Table 2-Mating types of the C. parasitica isolates and local hypovirulent strain in the research area

\begin{tabular}{ccc}
\hline Izolat sayıs & \multicolumn{3}{c}{ Eşleşme tipi } \\
\cline { 2 - 3 } & Mat1-1 & Mat 1-2 \\
\hline 25 & - & + \\
HiSF $_{1}$ & - & + \\
\hline
\end{tabular}

(+): Pozitif; (-): Negatif

Milgroom 2001). Bir bölgede birden fazla sayıda uyum grubunun varlığ 1 biyolojik mücadele çalışmasını oldukça güçleştiren bir özellik olarak kabul edilmektedir. (Heiniger \& Rigling 1994). Buna göre, çalışma alanında biyolojik çalışmaların yürütülmesinde patojenin genetik özelliklerinden kaynaklanabilecek bir olumsuzluk ortaya çıkmayacaktır.

\subsection{Kestanelikte yürütülen çalışmalarda elde edilen bulgular}

\subsubsection{Biyolojik mücadele bulgulart}

Deneme alanındaki 18 ağaç (25 ağaçtan 7'si kurumuştur) üzerindeki toplam 29 kansere 2003 yılında $\mathrm{HiSF}_{1}$ ile yapılan inokulasyonu takiben kanser boyutlarındaki değişimler, 1.5-2 ay ara ile 2005 yılına kadar yapılan ölçümlerle belirlenmiş ve bulgular Çizelge 3 'te verilmiştir. İlk yıl haziran ayı içinde inokule edilen ağaçlardan 8 tanesi (ağaç no:19, 30,33, 36, 76, 79, 91, 93) üzerindeki 10 kanser alanında büyüme olmazken, 2004 yılında, 11 ağaç (ağaç no: 18, X, 36, 53, 56, 73, 76, 79, 86, 91, 93) üzerindeki 13 kanserde iyileşme olmuştur. İnokulasyondan 3 yıl sonra, 6 ağaç (ağaç no: 18, $53,56,76,79,86)$ üzerindeki 7 iyileşen kanserin büyüklüğünde değişme olmamış, 7 ağaç (ağaç no: $\mathrm{X}, 18,30,36,73,91,93$ ) üzerindeki 10 kanser alanında büyüme olmuş, 6 ağaç (ağaç no: 9, 13, $17,19,33,54)$ ise kurumuştur.
Sonuç olarak, 2003 yılında kanser büyüklüklerinde genel olarak artış olmazken, 2004 yılında 8 ağaç üzerindeki 10 kanser iyileşme göstermiş, 2005 yılında 6 ağaç üzerindeki toplam 7 kanserde iyileşmenin devam ettiği saptanmıştır. İnokule edilen kanserlerdeki iyileşmeler hipovirulensliğin aktarılabilmesi nedeniyle meydana gelmiştir. Bazı kanserlerde kallus dokusunun oluşumuna bağlı olarak kanser alanı gittikçe küçülmüş ve patojenin üreme organlarını taşıyan stromalar kaybolmuştur. $\mathrm{Bu}$ konuda çalışan diğer araştırıcılar da iyileşme sürecinde kallus dokusu oluşumunun rol oynadığını ifade etmektedirler (Calza 1993). Bazı kanserlerde ise iyileşme, Dunn et al (1992)'ın da belirttiği gibi, aktif kanserlerin inokulasyondan sonra, siyahıms1kahverengiye dönüşmesi, kabukta yüzeysel çatlamaların ortaya çıkması, kanserin dokuda derinlemesine yayılmasının durması şeklinde olmuştur.

\subsubsection{Hipovirulent streynin doğal koşullardaki adaptasyonu}

Çalışmanın ilk yılında $\mathrm{HiSF}_{1}$ ile inokule edilen ağaçlardan 2004 ve 2005 yıllarında toplam 13 ağaç üzerindeki 20 iyileşen kanserden reizolasyonlar yapılmış ve bu iyileşen kanserlerden beyaz ( 74 adet ) ve turuncu ( 28 adet) renkli olmak üzere toplam 102 izolat elde edilmiştir. 
Çizelge 3-İnokule edilmiş ağaçlar üzerindeki kanserli alanların 2003-2005 yılları arasındaki dönemde gösterdikleri değişim

Table 3-Variation of the canker size on the inoculated trees during the period 2003-2005

\begin{tabular}{|c|c|c|c|c|c|c|c|c|}
\hline \multicolumn{9}{|c|}{ Kanser Alanlarl, $\mathrm{cm}^{2}$} \\
\hline Tarih & \multirow{2}{*}{$10.06 .2003^{1}$} & \multirow{2}{*}{22.07 .2003} & \multirow{2}{*}{02.09 .2003} & \multirow{2}{*}{21.10 .2003} & \multirow{2}{*}{20.05 .2004} & \multirow{2}{*}{06.07 .2004} & \multirow{2}{*}{ 21.9.2004 } & \multirow{2}{*}{ 15.6.2005 } \\
\hline A ğaç no & & & & & & & & \\
\hline \multirow{2}{*}{9} & 82.4 & 82.4 & 82.4 & Kurudu ${ }^{2}$ & Kurudu & Kurudu & Kurudu & Kurudu \\
\hline & 122 & 122 & 122 & & & & & \\
\hline 13 & 1374 & 1374 & 1403 & Kurudu & Kurudu & Kurudu & Kurudu & Kurudu \\
\hline 17 & 2872 & 2872 & 2918 & Kurudu & Kurudu & Kurudu & Kurudu & Kurudu \\
\hline \multirow[t]{2}{*}{18} & - & - & 265 & 265 & 306 & 306 & 103 & 72 \\
\hline & & & 117 & 117 & 137 & 137 & 196 & 196 \\
\hline \multirow[t]{2}{*}{19} & 337 & 337 & 337 & 337 & Kurudu & Kurudu & Kurudu & Kurudu \\
\hline & 2826 & 2826 & 2826 & 2826 & & & & \\
\hline \multirow[t]{3}{*}{$\mathrm{X}$} & - & - & 832 & 919 & 942 & 320 & 320 & 333 \\
\hline & & & 577 & 577 & 577 & 582 & 340 & 857 \\
\hline & & & 33 & 33.7 & 37.1 & 35 & 53 & \\
\hline 30 & 628 & 628 & 628 & 628 & 521 & 521 & 608 & 981 \\
\hline \multirow[t]{3}{*}{33} & 239 & 239 & 239 & 239 & Kurudu & Kurudu & Kurudu & Kurudu \\
\hline & 31 & 35 & 52 & 58 & & & & \\
\hline & 31 & 31 & 50 & 57 & & & & \\
\hline \multirow[t]{3}{*}{36} & 110 & 110 & 110 & 110 & 47 & 47 & 44 & 188 \\
\hline & 679 & 679 & 679 & 679 & 265 & 265 & 418 & 554 \\
\hline & & & 53 & 53 & 111 & 111 & 117 & 239 \\
\hline 53 & - & - & 94 & 94 & 90 & 74 & 64 & 30 \\
\hline 54 & 594 & 594 & 602 & 602 & 622 & 622 & 898 & Kurudu \\
\hline 56 & 131 & 131 & 176 & 176 & 251 & 256 & 173 & 173 \\
\hline 73 & 763 & 763 & 763 & 797 & 797 & 797 & 797 & 809 \\
\hline 76 & 459 & 459 & 459 & 459 & 459 & 459 & 459 & 163 \\
\hline 79 & 276 & 276 & 276 & 276 & 276 & 245 & 220 & 220 \\
\hline \multirow[t]{3}{*}{86} & 206 & 206 & 286 & 286 & 297 & 220 & 181 & 169 \\
\hline & & & 53 & 53 & 99 & 96 & 96 & 35 \\
\hline & & & & 40 & & & & \\
\hline 91 & 91 & 91 & 91 & 91 & 91 & 91 & 91 & 117 \\
\hline 93 & 176 & 176 & 176 & 176 & 176 & 54 & 44 & 98 \\
\hline
\end{tabular}

${ }^{1}$ İnokulasyon öncesi kanser büyüklüğü

${ }^{3}$ Kanser alanı elips formülüne göre hesaplanmıştır

Konversiyon testlerinde, beyaz renkli reizolatların turuncu izolatları dönüştürme yeteneğine sahip olduğu belirlenmiştir (Çizelge 4).

$\mathrm{Bu}$ sonuç, iyileşmenin hipovirulenslik nedeniyle olduğunu bir kez daha göstermekte ve inokulasyondan 2 yıl sonra da bu kanserlerden HiSF $_{1}$ 'in hala geri alınabilmesi, bu streynin doğaya adapte olabildiğine işaret etmektedir.

\subsubsection{Hipovirulensin doğada yayılımı}

Yapay inokulasyonlar sonucu kanserlerin iyileşmesini sağlayan hipovirulent streynin araştırma alanında doğal yayılma durumunu belirlemek amaciyla, 2004 yılından başlayarak 2007-2008 dönemine kadar sürdürülen gözlemler yapılmıştır. Çalışma alanında, 2006 yılına kadar yeni, iyileşen kanser meydana gelmezken, inokulasyondan 4 ve 5 yıl sonra, 2007 ve 2008 yıllarında, önceden inokule edilmiş 6 ağaç üzerinde 6 yeni iyileşmiş kanser, inokule edilmemiş 17 ağaç üzerinde ise 22 iyileşmiş kanser olmak üzere, toplam 23 ağaç üzerinde hepsi kallus dokusuna sahip 28 yeni iyileşen kanser meydana geldiği kaydedilmiştir (Çizelge 5). $\mathrm{Bu}$ durum çalışmanın önemli bir sonucunu 
Çizelge 4-Hipovirulent streyn ile inokule edilmiş kanserlerden elde edilen C. parasitica re-izolatlarının fenotipik özellikleri ve beyaz izolatların turuncu izolatları dönüş̧ürme yetenekleri

Table 4-Cultural phenotypes of the C. parasitica re-isolates from cankers inoculated with hypovirulent strain and ability of white isolates to convert orange isolates

\begin{tabular}{ccccccccc}
\hline & \multicolumn{7}{c}{ Elde edilen C.parasitica reizolatının fenotipik özelliği } \\
\cline { 2 - 8 } İzolat no & Kanser;üst & Dönüşüm & Kanser; alt & Dönüşüm & Kanser; sol & Dönüşüm & Kanser;sağ & Dönüşüm \\
\hline $18-1$ & $\mathrm{~B}$ & + & $\mathrm{B}$ & + & $\mathrm{B}$ & + & $\mathrm{B}$ & + \\
$18-2$ & $\mathrm{~B}, \mathrm{~T}$ & + & $\mathrm{B}$ & + & $\mathrm{B}$ & + & $\mathrm{B}, \mathrm{T}$ & + \\
$18-3$ & $\mathrm{~B}, \mathrm{~T}$ & + & $\mathrm{B}, \mathrm{T}$ & + & $\mathrm{B}, \mathrm{T}$ & + & $\mathrm{B}, \mathrm{T}$ & + \\
$\mathrm{X}-1$ & & & $\mathrm{~B}, \mathrm{~T}$ & + & $\mathrm{B}$ & + & $\mathrm{B}$ & + \\
$\mathrm{X}-2$ & $\mathrm{~B}$ & + & $\mathrm{B}$ & + & $\mathrm{B}$ & + & $\mathrm{B}$ & + \\
$\mathrm{X}-3$ & $\mathrm{~B}$ & + & $\mathrm{B}$ & + & $\mathrm{B}$ & + & $\mathrm{B}$ & + \\
30 & & & & & & & $\mathrm{~B}, \mathrm{~T}$ & + \\
$36-1$ & & & $\mathrm{~B}, \mathrm{~T}$ & + & $\mathrm{B}, \mathrm{T}$ & + & $\mathrm{B}$ & + \\
$36-2$ & $\mathrm{~B}, \mathrm{~B}$ & + & $\mathrm{B}$ & + & $\mathrm{B}$ & + & $\mathrm{B}, \mathrm{T}$ & + \\
$36-3$ & $\mathrm{~B}$ & + & $\mathrm{B}$ & + & $\mathrm{B}$ & + & $\mathrm{B}$ & + \\
53 & $\mathrm{~B}$ & + & $\mathrm{B}$ & + & $\mathrm{B}$ & + & $\mathrm{B}$ & + \\
54 & $\mathrm{~B}, \mathrm{~T}$ & + & $\mathrm{B}, \mathrm{T}$ & + & $\mathrm{B}$ & + & $\mathrm{B}$ & + \\
56 & $\mathrm{~B}$ & + & $\mathrm{B}$ & + & $\mathrm{B}$ & + & $\mathrm{B}$ & + \\
73 & $\mathrm{~B}, \mathrm{~T}$ & + & $\mathrm{B}$ & + & $\mathrm{T}$ & & $\mathrm{B}, \mathrm{T}$ & + \\
76 & $\mathrm{~B}$ & + & $\mathrm{B}, \mathrm{T}$ & + & $\mathrm{B}, \mathrm{T}$ & + & $\mathrm{B}, \mathrm{T}$ & + \\
79 & $\mathrm{~B}$ & + & $\mathrm{B}$ & + & $\mathrm{B}$ & + & $\mathrm{B}, \mathrm{T}$ & + \\
$86-1$ & $\mathrm{~B}$ & + & $\mathrm{B}$ & + & $\mathrm{B}, \mathrm{T}$ & + & $\mathrm{B}, \mathrm{T}$ & + \\
$86-2$ & $\mathrm{~B}$ & + & $\mathrm{B}$ & + & $\mathrm{B}$ & + & $\mathrm{B}$ & + \\
91 & $\mathrm{~B}, \mathrm{~T}$ & + & $\mathrm{B}, \mathrm{T}$ & + & $\mathrm{B}, \mathrm{T}$ & + & $\mathrm{B}, \mathrm{T}$ & + \\
93 & $\mathrm{~B}$ & + & $\mathrm{B}$ & + & $\mathrm{B}$ & + & $\mathrm{B}, \mathrm{T}$ & + \\
\hline
\end{tabular}

T:Turuncu; B:Beyaz; (+): Dönüştürme var

Çizelge 5-Doğal yayılım nedeniyle oluşan iyileşmiş kanserlerin durumu

Table 5-Presence of the healed cankers due to the natural dissemination

\begin{tabular}{|c|c|c|c|c|}
\hline \multirow[t]{3}{*}{ Yil } & \multicolumn{4}{|c|}{ İyileşmiş kanserlerin sayısı } \\
\hline & \multicolumn{2}{|c|}{ İnokule edilen ağaçların üstünde } & \multicolumn{2}{|c|}{ İnokule edilmemiş ağaçlar üzerinde } \\
\hline & Ağaç sayısı & İyileşmiş kanser sayısı & Ağaç sayıs1 & İyileşmiş kanser sayıs \\
\hline 2007 & 5 & 5 & 8 & 11 \\
\hline 2008 & 1 & 1 & 9 & 11 \\
\hline Toplam & 6 & 6 & 17 & 22 \\
\hline
\end{tabular}

oluşturmuş, kestaneliklere inokule edilecek olan hipovirulent streynlerin doğal olarak yayılabileceğine ve böylelikle ülkemizde de hastalığın biyolojik mücadelesinde ümit var sonuçların alınabileceğine dair kuvvetli bir kanaat oluşmasını sağlamıştır.

Deneme alanında, C. parasitica dışında, kestane ağaçlarının kurumasına neden olan başka etmenler de saptanmıştır. Bunlardan en önemlisi, bir yara paraziti olan ve ağaçların kabuk dokusunda gelişerek iletim demetlerinin zarar görmesine, ağaçların zaman içinde tamamen kurumasına neden olan Cytospora spp.'dir. Bu etmen genç kestane ağaçlarında (Çeliker \& Onoğur 2009b) ve bazı orman ağaçlarında kurumalara neden olmaktadır (Flynn 2003; Elşad 2001). Hipovirulent streyn ile inokule edilen ağaçların çoğundan Cytospora sp. izole edilmiştir. Kanımıza göre, iyileşmekte olan bazı kanserlerin boyutlarında büyüme olması, ya da üstünde iyileşen kanser bulunan ağaçların kuruması Cytospora sp. nedeniyle olmuştur. $\mathrm{Bu}$ durum biyolojik kontrol başarısının sayısal olarak azalmasına yol açmıştır. 
Kestane kanserinin biyolojik mücadelesinin başarısında rol oynayan önemli bir faktör de sanitasyon uygulamalarıdır (Heiniger \& Rigling 1994). Bu uygulamalar, özellikle doğal olarak hipovirulent ırkın bulunmadığı bir alanda, yapay inokulasyonlar yoluyla hipovirulent rrkın o alana yerleşmesini ve yayılmasını teşvik etmektedir. Ancak çalışmamızda, kuruyan dalların kesilmesi ve imhası gibi sanitasyon uygulamaları yaptırılamadığı için deneme alanındaki ağaçlarda yeni $C$. parasitica ve Cytospora sp. enfeksiyonları meydana gelmiştir.

\section{Sonuç}

Bu çalışma ile Türkiye'de hipovirulens aktarımı yoluyla kestane kanserine yakalanmış ağaçlarda iyileşme olabileceği ilk kez bu araştırmayla ortaya konulmuştur. $\mathrm{Bu}$ konuda daha ileri araştırmalar yürütülerek, başarı oranının geliştirilmesinde fayda bulunmaktadır.

\section{Teşekkür}

$\mathrm{Bu}$ projenin yürütülmesi için maddi destek sağlayan Gıda Tarım ve Hayvancılık Bakanlığı Tarımsal Araştırmalar Genel Müdürlüğü (TAGEM)'ne teşekkür ederiz.

\section{Kaynaklar}

Açıkgöz S, Döken T, Özdemir Z, Değirmenci F (2007). Determination of mating types of chestnut blight causal agent Cryphonectria parasitica (Murill) Barr; by multiplex PCR in Aydın province. Türkiye 2. Bitki Koruma Kongresi 27-29 Ağustos 2007 Isparta

Akıllı S, Katırcıŏlu Y Z \& Maden S (2009). Vegetative compatibility types of Cryphonectria parasitica, causal agent of Chestnut Blight, in the Black Sea Region. Turkey. Forest Pathology (39):390- 396

Akıllı S, Katırcıoğlu Y K\& Maden S (2011). Biological control of chestnut canker, caused by Cryphonectria parasitica, by antagonistic organisms and hypovirulent isolates. The Turkish Journal of Agriculture and Forestry 35(5):515-523

Aksoy M, Serdar Ü \& Soylu A (2005). Kestane fidanlarında kestane (Cryphonectria parasitica (Murrill) Barr karşı yapılan uygulamalar. OMÜ Ziraat Fakültesi Dergisi 20(1): 24- 29

Anonymous (2008). Zirai Mücadele Teknik Talimatları
Cilt.4 T.C.Tarım ve Köyişleri Bakanlığı. Tarımsal Araştırmalar Genel Müdürlüğü, Ankara

Bissegger M, Rigling D \& Heiniger U (1997). Population structure and disease development of Cryphonectria parasitica European chestnut forest in the presence of natural hypovirulence. Phytopathology 87:50- 59

Calza C A (1993). Biological control of chestnut blight: large-scale application techniques. Proceedings of the International Congress on Chestnut. Spoleto, Italy: 599- 602

Coşkun H, Turchetti T, Maresi G \& Santagana A (1999). Preliminary investigations into Cryphonectria parasitica (Murr.) Barr. isolates from Turkey. Phytopathology Mediterranea 38: 101- 110

Çeliker N M \& Onoğur E (1998). Determining the hypovirulence in the isolates of chestnut blight Cryphonectria parasitica (Murr.) Barr.) in Turkey. 'First record' The Journal of Turkish Phytopathology 27(2-3): 145- 146

Çeliker N M \& Onoğur E (2001). Evaluation of hypovirulent isolates of Cryphonectria parasitica for biological control of chestnut blight in Turkey. Forest Snow and Landscape Research 76(3): 378382

Çeliker N M \& Onoğur E (2004). Ege ve Marmara bölgelerinde kestane kanseri etmeni (Cryphonectria parasitica Murr.Barr)'nın yeni vejetatif uyum gruplarının oluşma şansı ve bunun biyolojik mücadele başarısına etkisi Türkiye 1. Bitki Koruma Kongresi 8-10 Eylül 2004 Samsun

Çeliker N M \& Onoğur E (2007). Kestane kanserinin (Cryphonectria parasitica Murr. Barr.) doğal koşullarda biyolojik mücadelesi. Türkiye 2. Bitki Koruma Kongresi 27-29 August 2007 Isparta

Çeliker N M \& Onoğur E (2009a). Actual Status of Biological control Studies on Chestnut Blight in Turkey. Actual Status of Biological control Studies on Chestnut Blight in Turkey, Proceedings of the First European Congrss on Chestnut Castanea 2009 ISSN 0567-7572 ISBN 978906605414 2, Acta Horticulturae 866: 369- 372

Çeliker N M \& Onoğur E (2009b). Preliminary studies on the fungal disorders especially on ink disease causing decline of chestnut trees in Turkey. International Workshop on Chestnut Management in Mediterranean Countries: Problems and Prospects 23-25 October 2007 Bursa, Turkey. ISBN 978906605178 2. Acta Horticulturae 815: 227-232

Döken M T, Açıkgöz S, Erincik Ö, Ertan E (2004). 
Studies in the chestnut growing areas of AydınTurkey to determine the incidence of Cryphonectria parasitica (Murill) Barr infections (Chestnut Blight) and vegetative compatibility group diversity among the isolates. Türkiye 1. Bitki Koruma Kongresi 8-10 Eylül Samsun

Dunn M, McKeen C \& G Boland (1992). Chestnut blight in Canada: Hipovirulence and biological control. Proceedings of the American Chestnut Symposium. Morgantown, West Virginia, July 1014. 1992 , pp. $147-155$

Elşad H (2001). Azerbaycan ormanlarında meşe ağaçlarına arız olan mikromantarlar. Turkish Journal of Agriculture and Forestry 25: 407- 413

Flynn P (2003). Cytospora canker of spruce. Department of Plant Pathology Iowa State University, Ames, Iowa. Available: http://www.ipm.iastate.edu/ipm/hortnews

Gurer, M, Ottaviani MP,\& Cortesi P (2001). Genetic diversity of subpopulations of Cryphonectria parasitica in Turkey. Forest Snow and Landscape Research 76: 383-386

Heiniger U \& Rigling D (1994). Biological control of chestnut blight in Europa. Annual Review of Phytopathology 32: 581-599

Marra E. R \& Milgroom M G (2001). The mating system of the fungus Cryphonectria parasitica: selfing and self-incompatibility. Heredity 86(2):134-143

Robin C \& Heiniger U (2001). Chestnut blight in Europe: Diversity of Cryphonectria parasitica, hypovirulence and biocontrol. Forest Snow and Landscape Research 76(3): 361-367 